\title{
Materialist Criticism: New Approaches
}

This issue of Praktyka Teoretyczna is an indirect result of some of the discussions that took place during the three-part conference Nowe/stare. Materializm $w$ literaturze, sztuce, krytyce (New/Old. Materialism in Literature, Art and Criticism) in Wrocław, Kraków and Łódź in 2018. The main goal of all three sessions was to arrange a space for a productive confrontation between the proponents of various conceptions of "materialism" in contemporary criticism, particularly those explicitly inter-ested in the so-called "new materialisms” ( Dolphijn \& van de Tuin 2012; Coole \& Frost 2010,) and those ascribing to a more openly Marxist tradition. (To a certain extent, we aimed to emphasise and collectively analyse, in very practical terms, the methodological tension described recently by Terry Eagleton [2016] and Slavoj Zizek [2014].) The focus was on literary criticism, art criticism and cul-tural criticism; but, presentations given during the conference touched on a variety of fields, subjects and media.

Among the issues we wanted to discuss were both certain methodological developments - such as the relationship between materialism and everyday life studies, sociology of objects/things, or con-temporary psychoanalysis—as well as the ostensibly more abstract, yet somewhat more practical issues of "doing criticism” in a way that responds to the material reality of the world around us, from the climate crisis to increasingly common precariousness to automation and the invention of new post-human/hybrid subjectivities.
Among the issues we wanted to discuss were both certain methodological developmentssuch as the relationship between materialism and everyday life studies, sociology of objects/ things, or con-temporary psychoanalysis-as well as the ostensibly more abstract, yet somewhat more practical issues of "doing criticism" in a way that responds to the material reality of the world around us, from the climate crisis to increasingly common precariousness to automation and the invention of new post-human/hybrid subjectivities. 
What became clear almost immediately, was that there was no clarity,at least when it came to the existence (or a lack thereof) of „camps” or "factions" amongst those of us interested in the ongoing materialist renewal within contemporary criticism. Whereas most of the conference participants - and, consequently, most of the authors published in this issue of Praktyka Teoretyczna — saw the "new materialisms” as an impor-

In other words, we debated both the theoretical and the practical implications of "new materialisms" to criticism-or a lack thereof-and this broad scope of debate is clearly reflected in the resulting issue of Praktyka Teoretyczna. tant point of reference, they varied wildly not only in their overall evaluation of the movement, but also when it came to the possibility of applying certain philosophi-cal developments to the more precise issues of literary and cultural criticism. In other words, we debated both the theoretical and the practical implications of „new materialisms” to criticism—or a lack thereof_-and this broad scope of debate is clearly reflected in the resulting issue of Praktyka Teoretyczna.

Among the most hotly debated issues was that of textuality and textualism, understood both as the-oretical/philosophical categories rooted in post-structuralist thought and French Theory, and as more practical issues to do with the everyday activities of a critic. The question of whether certain modes of criticism that appreciate and emphasise the textuality of the work of art/literature are in-compatible with an explicit focus on the materiality of such work, is raised in two very different ways by Joanna Orska and Krzysztof Uniłowski. Whereas Orska offers a deep dive into the work of Gilles Deleuze and Felix Guattari, rediscovering them as advocates of a certain notion or vision of textuality and literariness, Uniłowski reaches out into SF and contemporary game studies in order to point out certain practical and theoretical limits of a „materialist” approach to fiction.

Michał Krzykawski is also interested in the limits of new materiali$\mathrm{sm}(\mathrm{s})$, albeit from a more method-ological and institutional perspective. Drawing on the work of Bernard Stiegler, Krzykawski offers some fundamental critique of the global structure and power relations within academia, philosophy and criticism, in relation to new materialisms as a movement or tendency within contemporary thought. His article focuses on the issues of technology and cybernetics, their (relatively) recent yet underappreciated influence on theory and criticism, and the changes they seem to necessitate in the context of our notion of knowledge.

On the other side of the spectrum, in a way, lies the article by Marta Baron. Here, the author offers a close, methodical reading of select writings associated with the Futurist movement, emphasising the issues of procreation, reproduction and the creation of life. By embedding these issues in a broader biopolitical contexts (including Roberto Espo- 
sito's dialectic of immunisation and communisation), Baron sketches out a possibility of a materialist reading that transcends and subverts the traditional „vitalist” framework.

Articles by Anna Kałuża and Marta Koronkiewicz each offer a vision of a materialist poetics rooted in the work of specific authors, writers and poets. Kałuża draws parallels between the poems of Ad-am Kaczanowski, the photographic work of Andrzej Tobis and the „active poetry” of Ewa Partum, in order to showcase the various aspects of what she dubs the "neo-materialist” aesthetics in con-temporary Polish poetry and culture. Koronkiewicz, on the other hand, shows how a careful (re) reading of a certain tradition in Polish poetry-one that connects Adam Ważyk and Andrzej Sosnowski-may serve to deepen our understanding of the relationship between materialism and the literary form, and broaden the debate associated with the „new formalist” movement in literary history.

The latter is also among the primary objects of interest in Katarzyna Trzeciak's piece. Tracing back the development of a „post-critical tendency" in the contemporary humanities, Trzeciak seeks to escape the dichotomy of the „suspicious”, „unmasking” criticism and the criticism based on straight-forward "affirmation,"by establishing a new model of criticism and knowledge, one that is both material and contextual in its approach.

Finally, Paweł Kaczmarski seeks to prove that materialism in literary criticism is not only compatible with the so-called „strong” intentionalism of Walter Benn Michaels and the "nonsite school”; the latter, Kaczmarski argues, is the only credible foundation for any "materialist” approach to text.

It is the editors' hope that, taken as a whole, this issue of Praktyka Teoretyczna offers not so much a definitive answer to what it means to engage in materialist criticism today, or even a coherent narra-tive on the recent developments in materialist criticism, but rather, a collection of voices that further expand the debate on the issues currently shaping this dynamic and hotly contested field.

\section{References}

Coole Diana and Samantha Frost. 2010. New Materialisms: Ontology, Agency and Politics. Duhram and London: Duke University Press. Dolphijn Rick and Iris van der Tuin (ed.). 2012. New Materialism: 
Interviews and Cartographies. Ann Arbor: Open Humanities Press. Eagleton Terry. 2016. Materialism. London and New Haven: Yale University Press.

Žižek Slavoj. 2014. „Materialism, old and new”. Strike, Issue 8.

Citation: Praktyka Teoretyczna. 2019. „Materialist Criticism: New Approaches". Praktyka Teoretyczna 4(34): 7-10.

DOI: $10.14746 /$ prt2019.4.1

Author: Theoretical Practice

Title: Krytyka materialistyczna: nowe podejścia 